\title{
Promoting Entrepreneurial Mindset and Practice Through Online Bootcamp in COVID-19
}

\author{
Ning Tate Cao \\ Ron and Jane Graham School of Professional Development \\ University of Saskatchewan \\ tate.cao@usask.ca
}

\begin{abstract}
The rise of technology-based companies greatly changed the economic developments over the past few decades by commercialization of innovation. As a result, employers need more graduates with the mindset and skills to recognize and create innovative entrepreneurship or intrapreneurship opportunities. To meet this increasing demand, many engineering schools attempted to generate the talent and skills of future engineers, the methodology for commercializing new technological innovation started to form.
\end{abstract}

However, there are gaps in terms of the practice of delivering entrepreneurship education to engineering students in an effective manner. This is due to three major challenges in this COVID-19 pandemic era. First, the traditional engineering education program was developed during the post-war era, it focuses on contents and designs. While these address certain skills for entrepreneurship, the program design does not provide opportunities to develop important skills such as cross-disciplinary collaboration, tolerance to risk and failure. Second, the traditional program also creates another challenge due to its heavy math and science-focused content, as a result, most of the engineering programs are packed in terms of student schedule, leaving very little room for students to different or enhance their education by taking additional educational opportunities in entrepreneurship. And lastly, the adoption of online education for engineering entrepreneurship remains low. Thus, the literature provides little insights on how to effectively deliver, practice and evaluate the learnings of engineering entrepreneurship education remotely for degree-granting institutions.

The following article proposed a weeklong Bootcamp to introduce students to a robust process to instill an entrepreneurial mindset and practice. The structure and delivery of the Bootcamp through an online platform are discussed in detail along with student feedback.

Keywords: Entrepreneurship Education; Engineering Education; Technology Commercialization; Online Delivery; Pitch Competition

\section{INTRODUCTION}

The rise of technological innovation-based companies greatly changed the economic developments over the past few decades by commercialization of scientific and technology-driven innovations. As a result, employers and policymakers alike demand more graduates with the mindset and skills to recognize and create innovative entrepreneurship or intrapreneurship opportunities in order to remain competitive [1]. Furthermore, Engineers Canada has identified "entrepreneurship, innovation, and creativity" as one of the five core values for the engineering profession in Canada [2]. To meet this increasing demand, many engineering schools attempted to generate the talent and skills of future engineers, the methodology for commercializing new technological innovation started to form [3]. However, one gap remains. The engineering schools were never designed to deliver entrepreneurship education.

This challenge is further exaggerated in the era of the COVID19 pandemic. After the World Health Organization (WHO) declared COVID19 as a global pandemic in March 2020, engineering schools across Canada were forced to quickly adapt to the new situation and moved their class offerings online. This change provided opportunities for students to continue to study in a safe environment. However, due to engineering's heavy needs for in-person laboratories in many disciplines, and the fact of its heavy curriculum that is not easy to deliver over the remote setting, many students took a gap year or a reduced course load in the fall of 2020 [4]. The trend of this reduced course enrollment also impacted entrepreneurship classes. For many students, studying entrepreneurship is an enhancement for their disciplinary knowledge rather than required learning. Furthermore, many of the students enrolled in engineering schools are international students. Due to the travel restrictions, many of these students may not be able to travel to Canada. These barriers may further prohibit students from committing to additional classes. Engineering educators need to face these challenges to engage with students and to provide high-quality training to the intended student audience.

On the other hand, literature has shown that technological innovation-based businesses tended to form 
in times of financial downturns [5]. The economic downturn often leads to the scarcity of employment opportunities, access to the capitals, and uncertainties in the business context. These factors may influence a potential entrepreneur's perception of risk, entrepreneurial intention, as well as motivations. The lack of training may result in a higher failure rate of startup activities. It is particularly true in the technology innovation ventures where the market condition and business models are highly uncertain.

The faculty members across the country are challenged to practice what we preach: to pivot and quickly adapt to the changing business context. This leads to our research question: Is it possible to encourage students to develop an entrepreneurial spirit and to provide systematic progress to move students from the technical domain to the entrepreneurial domain in an online environment?

In the next session, the author will explore the experience of how the instruction teams at the University of Saskatchewan to adopt in the era of COVID19, and the application of using a pilot online Startup Bootcamp workshop to facilitate the learning needed for entrepreneurial skills.

\section{PROGRAM DESIGN}

Entrepreneurship education started in the 1950s. The first course in entrepreneurship education was offered at Harvard Business School in 1947. The entrepreneurship education focused on identifying and fostering a meticulous individual who is the "born entrepreneur". It is not until the late 1980s new conceptual frameworks were developed to consider entrepreneurship as a behavioralbased process. Modern views of entrepreneurship continuously evolve over the last few decades. It is widely accepted now that the team-based experiential learning model is the best practice in fostering entrepreneurship learning. The following models are incorporated with our program design and delivery.

Over the past decades, technology-based innovation became more significant in terms of job creation, wealth generation, as well as introducing innovation, national competitiveness. As a result, entrepreneurship education has grown significantly across the globe to meet the increasing demands of entrepreneurial mindsets and skills. Traditionally, entrepreneurship has been conducted through business schools. As a result, entrepreneurship has often been equated with small business [6]. The essence of commercializing a new technology is different from the traditional small business creation. Successful entrepreneurial ventures rely on creativity and innovation, where innovation must be considered as the successful integration of invention and commercialization. Furthermore, Engineers Canada has identified "entrepreneurship, innovation, and creativity" as one of the five core values for the engineering profession in Canada. As a result, more and more engineering faculties in Canadian institutions started to offer various levels of entrepreneurship programming within their faculties.

First of its kind in Canada, the Ron and Jane Graham School of Professional Development was founded in 2012. The initial focus of the school was to develop and foster better "soft" skills in the engineering students, particularly communication skills. The school took over the coordination of the Engineering Entrepreneurship Option (EEO) in 2015 [7]. The EEO was implemented in 2009 in collaboration with the Edwards School of Business. It is an undergraduate engineering program that consists of seven courses. In 2019, the program was redesigned based on market research and student feedback to the Technological Innovation Certificate (TIC). The new program is open to a broader audience and has a stronger focus on Innovation and Design to better meet the needs for technologicalbased entrepreneurship.

\subsection{Experiential Learning}

Traditional entrepreneurial classes were developed based on business management and leadership theories. As such, the course focused on the "know-what" hard fact content of business basics and skills [8]. As a result, the entrepreneurial course becomes learning about entrepreneurship instead of preparing students to become an entrepreneur. Furthermore, entrepreneurship education needs to look beyond the classroom and foster the "can-do" convention and "will do" attitude and action. These learning outcomes are highly relevant to entrepreneurship practice and yet difficult to teach, as shown in Figure 1.

Engineering entrepreneurship education requires reallife immersion and hands-on experiential learning in order to provide relevant entrepreneurship outcomes [9]. In a typical engineering entrepreneurship education context, hands-on learning is done through Problem-Based Learning (PBL). As one of the most widely used teaching methods, PBL is a student-centric learning approach, where the instructor act primarily in the role of facilitator. In PBL students work in teams to solve a loosely-structured complex real-life problem [10]. PBL is characterized by student-driven activities. The students can decide how deeply they engage with the problem. The students will also receive feedback from their peers as well as instructors [11].

In a virtual environment, it is extremely difficult to provide high-quality real-life experiential learning. The instructors need to provide support for the students to collaborate in a team fashion and to engage in peer feedback and learning [12]. Furthermore, the instructors should build on their facilitator role, to engage and 
facilitate frequent communication and organized group discussions.

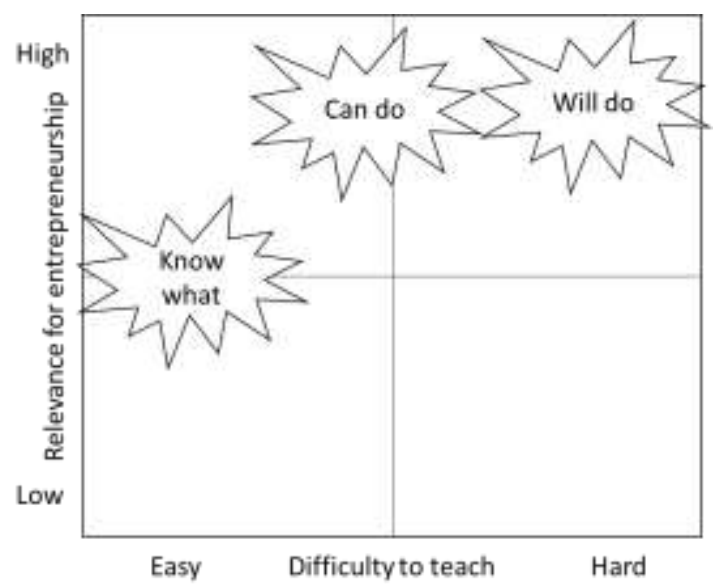

Figure 1 Entrepreneurship Educational Matrix, modified based on Haase (2011) [8]

\subsection{Disciplined Entrepreneurship Framework}

One of the challenges of teaching engineering entrepreneurship is the vast body of knowledge involved in entrepreneurship practice and the lack of agreement of the essential practice of entrepreneurship. Widely employed frameworks including Design Thinking and Lean Methodology tend to focus on the product definition phase [13][14]. The business aspects such as marketing and sales are rarely incorporated in the design courses.

One of the frameworks that combined different tool kits to facilitate a systematic process of technology innovationbased entrepreneurship is the Disciplined Entrepreneurship (DE) Framework developed by Bill Aulet from MIT, shown in Figure 2 [15]. The framework draws parallels between venture creation and the engineering design process. It views the venture creation process as the application of a set of techniques and skills that can be learnt and applied in a systematic fashion. The framework goes through a step by step process to answer the key questions that need to be answered during the Product Definition and Venture Creation process in six stages: 1) who is your customer, 2) what can you uniquely do for your customer, 3) how does your customer acquire your product, 4) how do you make money off your product, 5) how do you design and build your product, as well as 6) how do you scale your business.

In this framework, the students will complete product definition using System Thinking. The framework integrates marketing considerations in each step of the process. The students will assess the potential market size and market characteristics as they study the problem. Once a conceptual design is defined, the students are encouraged to produce low fidelity prototype in the form of a brochure to engage further market validation. The students will also design the sales funnel, business model, as well as pricing strategy as they define the product feature. The students may need to go back to previous steps to iterate. At the end of this iterative process, the students will be able to define a minimal viable business product (MVBP), as well as its associated business model.

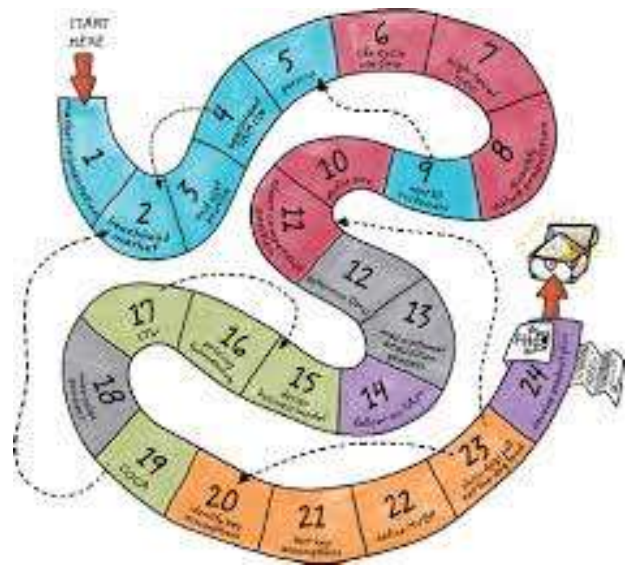

Figure 2 Disciplined Entrepreneurship Framework [15]

\subsection{Professional and Investor Network}

While most of the literature and framework focused on the importance of knowledge and skills of the entrepreneurs. It is worth noting that based on the data and research finding from entrepreneurial intermediaries such as the Global Accelerator Learning Initiative (GALI), the most important benefits from the accelerator programs are the "network development with potential partners and customers", "connections to funders", and "mentorship" [16]. These professional connections provide years of experience for the students to avoid typical mistakes in a particular industry. The personal connection with the potential investors will also create trust and alignment between the investors and student entrepreneurs.

Our work considered the importance of such benefits and focused on facilitating the student founders' professional networks. Mentorship is designed to be an intriguing part of the program.

\section{PROGRAM DELIVERY}

The Bootcamp is designed to teach a rigorous systematic entrepreneurial venture design process to technical students. It prepares them to accelerate their learning and practice in moving their engineering design or research work towards early-stage ventures.

The Bootcamp is a five-day event carefully designed to support the learning outcomes listed in Table 1 below. These learning outcomes are designed based on the frameworks and literature findings presented in Section 2. 
The Bootcamp was delivered to students who self-select to commit to this Bootcamp over the last week of September. The workshop was delivered by four faculty members and serval community volunteer mentors.

Table 1 The Bootcamp Learning Outcomes

\begin{tabular}{|c|c|}
\hline Workshop & Content \& Outcomes \\
\hline \multicolumn{2}{|l|}{ Day 1} \\
\hline Overview & $\begin{array}{ll}\text { - } & \text { Entrepreneurship can be taught. } \\
\text { - } & \text { Personal passion and vision }\end{array}$ \\
\hline Team Formation & $\begin{array}{ll}\text { - } & \text { Group work } \\
\text { - } & \text { Team }\end{array}$ \\
\hline Ideation & $\begin{array}{ll}\text { - } & \text { How to generate ideas } \\
\text { - } & \text { Initial idea }\end{array}$ \\
\hline Legal Clinic & - $\quad$ Basics business law \\
\hline \multicolumn{2}{|l|}{ Day 2} \\
\hline Customer & - $\quad$ Different types of customers \\
\hline $\begin{array}{l}\text { Primary Market } \\
\text { Research (PMR) }\end{array}$ & $\begin{array}{l}\text { - Methods of how to conduct } \\
\text { customer-focused research }\end{array}$ \\
\hline $\begin{array}{l}\text { Industry Leader } \\
\text { Panel }\end{array}$ & $\begin{array}{llll}\text { - } & \begin{array}{l}\text { Industry leaders from related } \\
\text { sectors }\end{array} \\
\end{array}$ \\
\hline \multicolumn{2}{|l|}{ Day 3} \\
\hline Money & Sales process based on PMR \\
\hline Money 2 & - $\quad$ Business model and pricing strategy \\
\hline \multicolumn{2}{|l|}{ Pitch Basics } \\
\hline $\begin{array}{l}\mathrm{VC} / \text { Angel } \\
\text { Investors Panel }\end{array}$ & $\begin{array}{ll}\text { - } & \text { What the investors look for } \\
\text { - } & \text { Fundraising plan }\end{array}$ \\
\hline \multicolumn{2}{|l|}{ Day 4} \\
\hline Groupwork Time & $\begin{array}{ll}\text { - Teams work on their business } \\
\text { model and pitch }\end{array}$ \\
\hline Speaker & - $\quad$ Entrepreneurial Strategy \\
\hline Financial Clinic & Supports on financial forecasts \\
\hline Board Meeting & Pre-pitch to a panel of mentors \\
\hline \multicolumn{2}{|l|}{ Day 5} \\
\hline Pitch Clinic & - $\quad$ Further support on developing pitch \\
\hline $\begin{array}{l}\text { Pitch } \\
\text { Competition }\end{array}$ & $\begin{array}{l}\text { - Pitch MVBP and Business Model to } \\
\text { panel judges. }\end{array}$ \\
\hline
\end{tabular}

\subsection{Pre-Program Engagement and Online Platforms}

Due to the remote nature of the program, we decided to use the online conference tool WebEx for most of the delivery and interactions. Breakout rooms were used to increase the students' group interaction during the workshop.

Prior to the Bootcamp, instructions were sent out to the students regarding the communication platforms. A Slack channel was set to facilitate student interactions as well as team formations. Students were also given instructions regarding the logistics of the workshop beforehand, including a Personality test that is based on Myers- Briggs.

Based on the information provided by the students on the application form, for this cohort, we had twenty-four participants. Ten were graduate students and fourteen were undergraduate students. As shown in Figure 3, these students focused on six main industry sectors: 1) Health care, 2) Cleantech, 3) Consumer, 4) Agricultural, 5) FinTech, and 6) Artificial Intelligence. This information was then used to recruit community mentors to provide sector-specific expertise to the students.

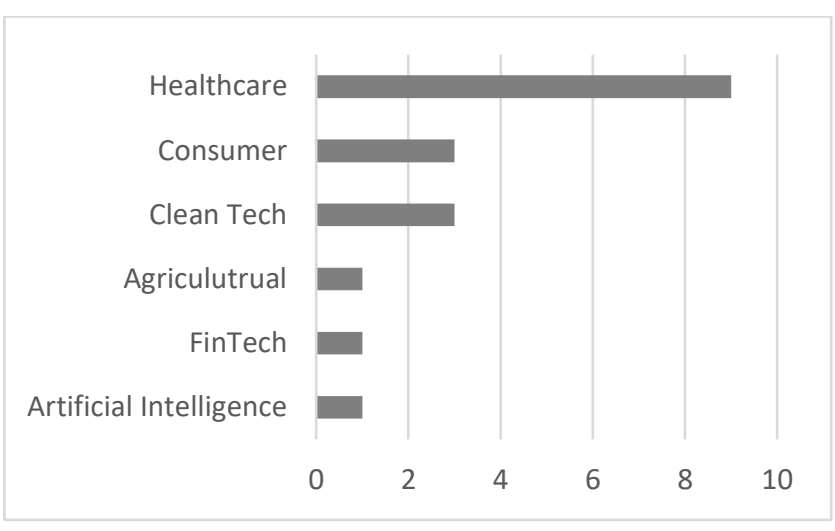

Figure 3 The Industries Bootcamp Attendees Pursued

\subsection{Overview and Team Building}

The first day served as an introduction session between the instructional team, mentors, and the students. It also provided the outline of the critical components of the program Bootcamp. Each workshop is delivered by a different instructor with mentors from the professional community.

The first workshop focused on motivating the students by showcasing alumni success and explaining the DE Framework that will be used in the workshop.

The second workshop focused on team building and team dynamics. During this session, the students were given opportunities to present their ideas to each other, learn about each other's personalities obtained from the personality test, as well as strategies to work in teams based on personality and skillsets.

\subsection{Business Legal Considerations}

At the end of the first day, a legal practitioner who focused on startup legal consultation presented typical legal considerations when the students found a startup company, including 1) founder issues, 2) equity split, 3) intellectual property, and 4) general business laws. The students were encouraged to engage and interact with the legal support before they move forward on their startup journey.

\subsection{Customer Discovery and Primary Market Research}

On the second day of the Bootcamp, the workshops focused on the market and product fit. Despite typical engineering, design training provides opportunities for customer engagements and interviews. These engagements 
typically focus on the identification of a problem and the creation of a solution. To shorten the learning efforts, the first workshop focused on introducing different types of customers involved in pursuing and using a product or service.

The second workshop focused on the techniques for collecting user data. Specifically, the students were given instructions on how to identify customer needs through interviews and how to prioritize these needs. The students were then given opportunities to practice these skills.

\subsection{Industry Expert Panel}

Following the workshops on the second day, the students met with a panel of industry leaders to deeply understand the specific needs and processes involved in the industries they targeted. Based on the students' responses from their application, three experts involved in consumer service, Software as a Service (SaaS), Supply Chain, Distribution Channels, and Manufacturing were brought in to provide information and network for student founders.

\subsection{Sales Process and Business Model}

The third day began with three workshops on how to capture the value created by the products. The first workshop built on the understanding from the Industry Expert Panel to develop a potential Business Model using Business Model Canvas [17].

The second workshop dived deeper into the Business Model Canvas to refine the Sales Process using BMC, Sales Funnel [18], and Customer Journey Maps [19].

The third workshop focused on the best practices of developing and delivering an investor pitch. The workshop followed the Ten Slides Pitch Approach developed by Guy Kawasaki [20]. The rubric with the specific evaluation criteria is given to the students to prepare and practice their pitches ahead of time.

\subsection{Investor Network}

Following the workshops on the third day, the students met with a panel of investors ranging from angel investors, venture capitalists and government support agencies. The panelists provided information regarding the types of business they invested in, the typical size of the investments, the timetable for a return on their capital, as well as the importance of alignment of ethics and visions between founders and investors.

The students are then given opportunities to work on their capital planning and fundraising plan based on the information they received and their product plans.

\subsection{Board Meeting and Mentorship}

On the fourth day, the students were given time to work in groups to practice and refine their pitches. An optional guest lecture on Entrepreneurial Strategies and Intellectual Property was provided in collaboration with the Speaker Series Course.

The students then had the opportunity to pitch their current work in process in a mocked board meeting. The instruction team, entrepreneur in residence and community mentors provided feedback to refine the product definition, market validation, as well as the business model developed using skillsets presented in the previous days.

\subsection{Pitching Competition}

Finally, the students delivered their pitch presentation to a panel of external judges. Each team was given a tenminute time limit and the teams who exceeded the limit would be muted. After each pitch, the judges would ask clarification questions and provide feedback to promote the students' ability to critically examine their product offerings and business models.

\section{DISCUSSION}

To access the effectiveness of the Bootcamp, we reviewed the feedback from student participants as well as mentors involved in the process.

Based on the feedback, most of the students ranked the connection with industry experts and potential investors as the most important learning outcome, similar to the previous study. Currently, there are five student teams out of the Bootcamp workshop actively pursuing entrepreneurship. Two of the teams moved into the revenue stage. Furthermore, based on the student feedback, the Startup Bootcamp received a Net Promoter Score (NPS) of 7.5. It shows that the students are satisfied with the program and will likely actively promote the program to their friends [21].

Finally, we received positive requests from students and even faculty members outside of the College of Engineering and the University of Saskatchewan as well as investors for opportunities to participate and collaborate on future Bootcamp sessions. These further confirm that such an experience could be beneficial to students and professionals alike.

\section{CONCLUSION}

As a pilot project, the Startup Bootcamp received positive feedback from both the student and investor community, we are eager to continue to offer this program to future participants. We are eager to learn about other institutions' offerings in terms of engineering entrepreneurship and your experience in the delivery and follow-ups. 


\section{Acknowledgements}

The author wishes to thank the La Borde Family Endowment Fund for the financial support for the design and delivery of the Bootcamp, the colleagues from the University of Saskatchewan and the community mentors who contributed their knowledge and time, as well as the Canadian Engineering Education Association (CEEA)'s Board of Directors for supporting the formation of the Engineering Entrepreneurship and Technology Innovation Special Interest Group (SIG), along with all the colleagues who contributed to this work.

\section{References}

[1] T. N. Cao et al., "A Snapshot of Entrepreneurship Education at Canadian Engineering Schools - A Representative Overview from EETI SIG Members," Proc. Can. Eng. Educ. Assoc., pp. 1-7, 2020, doi: 10.24908/pceea.vi0.14180.

[2] E. Canada, "Vision for the Engineering Profession," Ottawa, 2009.

[3] D. J. Deming, N. Yuchtman, A. Abulafi, C. Goldin, and L. F. Katz, "The value of postsecondary credentials in the labor market: An experimental study," Am. Econ. Rev., vol. 106, no. 3, pp. 778-806, 2016, doi: 10.1257/aer.20141757.

[4] "Gap year gaining popularity thanks to COVID-19| CBC News."

https://www.cbc.ca/news/canada/ottawa/gap-yearcovid-online-classes-1.5568217 (accessed Mar. 07, 2021).

[5] A. M. Wolfson, "Technological innovation, venture formation and resource allocation: the impact of economic downturn on life sciences venture capital and start-ups (Doctoral dissertation), 2010.

[6] D. A. Kirby, "Entrepreneurship education: Can business schools meet the challenge?," Educ. + Train., vol. 46, pp. 510-519, 2004, doi:

$10.1108 / 00400910410569632$.

[7] C. D'Amours, C. Laguë, and F. Mellor, "Entrepreneurship curricula and competitions at the Faculty of Engineering of the University of Ottawa," ASEE Annu. Conf. Expo. Conf. Proc., 2009, doi: 10.18260/1-2--4665.

[8] H. Haase and A. Lautenschläger, "The 'Teachability Dilemma' of entrepreneurship," Int. Entrep. Manag. J., vol. 7, no. 2, pp. 145-162, 2011, doi: 10.1007/s11365010-0150-3.

[9] L. Castaldi, E. Sepe, C. Turi, and V. Iscaro, “An experiential learning program for entrepreneurship education," Glob. Bus. Econ. Rev., vol. 22, no. 1-2, pp. 178-197, 2020, doi: 10.1504/GBER.2020.105050. project performance in entrepreneurship education: Learning in a lean startup environment," Technol. Forecast. Soc. Change, vol. 100, pp. 21-28, 2015, doi: 10.1016/j.techfore.2015.02.007.

[11] R. Hanke and E. Kisenwether, "A SCALABLE PROBLEM-BASED LEARNING SYSTEM FOR ENTREPRENEURSHIP EDUCATION," Ecol. Manag. Restor., vol. 6, no. 2, pp. 156-156, 2005.

[12] L. Cooperman, "So You Want to Teach Online," Art Teach. Online, pp. 1-5, 2018, doi: 10.1016/b978-0-08101013-6.00001-1.

[13] C. L. Dym, A. M. Agogino, O. Eris, D. D. Frey, and L. J. Leifer, "Engineering design thinking, teaching, and learning," IEEE Eng. Manag. Rev., vol. 34, no. 1, pp. 65-90, 2006, doi: 10.1109/emr.2006.1679078.

[14] C. Nobel, "Teaching a 'Lean Startup' Strategy," Harvard Bus. Sch., pp. 1-2, 2011, [Online]. Available: http://hbswk.hbs.edu/pdf/item/6659.pdf.

[15] D. N. Sull, "Disciplined entrepreneurship," MIT Sloan Management Review, vol. 46, no. 1. 2004.

[16] GALI, "The Entrepreneurship Database Program at Emory University 2018 Year-End Data Summary," no. May, pp. 1-10, 2019.

[17] Y. P. A Osterwalder, Business model canvas. 2010.

[18] M. J. Cooper and C. S. Budd, "Tying the pieces together: A normative framework for integrating sales and project operations," Ind. Mark. Manag., vol. 36, no. 2, pp. 173-182, 2007, doi: 10.1016/j.indmarman.2006.03.005.

[19] "Using Customer Journey Maps to Improve Customer Experience." https://hbr.org/2010/11/using-customerjourney-maps-to (accessed Mar. 07, 2021).

[20] "The Only 10 Slides You Need in Your Pitch - Guy Kawasaki." https:/guykawasaki.com/the-only-10slides-you-need-in-your-pitch/ (accessed Mar. 07, 2021).

[21] "What Is Net Promoter?" https://www.netpromoter.com/know/ (accessed Mar. 07, 2021). 